\title{
Insect Transmission of Xylella fastidiosa to Pecan
}

\author{
R. S. Sanderlin, Louisiana State University Agricultural Center Pecan Research-Extension Station, P.O. Box 5519, \\ Shreveport 71135; and R. A. Melanson, Louisiana State University Agricultural Center Plant Pathology and Crop \\ Physiology Department, Baton Rouge 70803
}

\begin{abstract}
Sanderlin, R. S., and Melanson, R. A. 2010. Insect transmission of Xylella fastidiosa to pecan. Plant Dis. 94:465-470.

Pecan bacterial leaf scorch (PBLS), caused by the bacterium Xylella fastidiosa, can cause economically significant crop loss to some pecan (Carya illinoinensis) cultivars in the southeastern United States. X. fastidiosa is typically vectored by spittlebugs (Cercopidae) and leafhoppers (Cicadellidae). Because no vector species had been reported for pecan, an attempt was made to identify potential vectors that are capable of acquiring the bacterium from infected pecan trees and transmitting to pecan. Several spittlebug and leafhopper species collected from various sources, including sorghum and pecan, were tested as potential vectors of the pathogen from pecan to pecan. When tested in groups, the pecan spittlebug, Clastoptera achatina; the Johnsongrass sharpshooter, Homalodisca insolita; and the glassy-winged sharpshooter (GWSS), Homalodisca vitripennis, had transmission rates to pecan of $11.4,19.3$, and $4 \%$, respectively, following a pathogen acquisition period on infected pecan terminals. The pecan spittlebug is common in pecan orchards in the southeastern United States, and the GWSS was observed on young vigorous pecan shoots. Limited testing with the diamond-backed spittlebug, Lepyronia quadrangularis, and the lateral-lined sharpshooter, Cuerna costalis, suggested that these could be occasional vectors of $X$. fastidiosa to pecan. There is a need for studies on the identification and population dynamics of Cicadellidae that inhabit pecan orchards to determine if management of vectors is needed in commercial pecan production to reduce the spread of PBLS.
\end{abstract}

Pecan (Carya illinoinensis (Wangenheim) K. Koch) is one of the few economically important native horticultural crops in North America. In the United States, it is grown commercially throughout the southeastern states, in parts of the midsouth, and in some areas of the southwest (42). Pecan bacterial leaf scorch (PBLS) (35) is caused by the bacterial pathogen Xylella fastidiosa Wells et al., which causes disease in many horticultural crops and landscape trees including grape, peach, plum, almond, sycamore, oak, and red maple $(19,20)$. Four subspecies of $X$. fastidiosa have been described (38-40); the pecan strain appears to belong to the multiplex subspecies (R. Melanson, unpublished). $X$. fastidiosa resides in the xylem tissue of the host plants it infects, producing diseases that typically cause defoliation, reduction in plant growth, and sometimes plant death (16). In pecan, $X$. fastidiosa can cause significant yield reduction and defoliation in susceptible cultivars (36). Disease development tends to be chronic, occurring at varying levels of severity annually. Disease symptoms can

Corresponding author: R. S. Sanderlin

E-mail: rsanderlin@agcenter.lsu.edu

Accepted for publication 30 December 2009.

doi:10.1094/PDIS-94-4-0465

(c) 2010 The American Phytopathological Society occur in one or several limbs, eventually spreading throughout the tree. Visual symptoms include leaflets turning tan to brown at the margins and necrosis progressing basipetally toward the midrib and petiolule, followed by abscission of affected leaflets and rachises (35).

The primary means of $X$. fastidiosa transmission is insect vectoring. Insect vectors are limited to members of the $\mathrm{Ci}$ cadellidae (leafhoppers) and Cercopidae (spittlebugs) (19,34). Most of the insect vectors identified in the southeastern United States have been in studies of Vitis and Prunus species $(19,26)$. PBLS has been observed to spread within pecan orchards (R. Sanderlin, unpublished), but no insect vectors have been reported for $X$. fastidiosa on pecan. Determination of insect vectors of the PBLS pathogen in pecan could lead to management measures to help reduce pathogen spread in commercial orchards. The objective of this research was to identify potential insect vectors of $X$. fastidiosa in pecan.

\section{MATERIALS AND METHODS}

Tree source and general transmission test procedures. Nongrafted pecan trees grown from seed of the PBLS-susceptible cultivar Cape Fear were used as hosts for transmission tests. Seed collected from noninfected Cape Fear trees the previous year and stored at 4 to $7^{\circ} \mathrm{C}$ were germinated in a growth chamber near $32^{\circ} \mathrm{C}$ before being transplanted individually into pots. In 2004, germinated seeds were transplanted into 18.9-liter (5 gal) pots using Metro Mix 250 growth medium (SunGro Horticulture Distribution, Inc., Bellevue, WA). In succeeding years, the germinated seed were transplanted to 7.6liter (2 gal) pots in Metro-Mix 702. Trees used in the transmission tests were generally 25 to $38 \mathrm{~cm}$ in height. Excess trees not used in transmission tests and maintained in the greenhouse $(14.6 \times 9.1 \mathrm{~m})$ were used as checks for detection of errant transmission events (greenhouse controls).

Because of a shortage of Cape Fear seed, 42 of 261 trees used in transmission tests in 2004 and 2005 were grown from seed of cultivar Desirable, another PBLSsusceptible cultivar. Trees were produced as described for Cape Fear. Because there was no difference in percent infection between the two seed sources (chi-square test, $P=0.41$ ), the results were combined.

Insects were maintained on test trees with cylindrical wire cages covered with white organdy cloth. Following insect transfer, cage tops were sealed with aluminum foil. The inoculation access period (IAP) for insect nymphs was in a greenhouse. All adult (winged) insects were given IAPs in the lab to prevent escapes in the greenhouse. Following the IAP, trees were maintained in a greenhouse in a randomized design. Prior to the IAP, insects were usually given an acquisition access period (AAP) on infected pecan tissue to increase chances of exposure to the pathogen. Symptomatic terminals of infected orchard trees, symptomatic trees in pots, or symptomatic terminals cut from trees and maintained in water in the lab were used as pathogen-source plant tissue.

Spittlebug transmission tests. Pecan spittlebug, Clastoptera achatina Germar, nymphs and adults were collected from an orchard near Cloutierville, LA $\left(31^{\circ} 32^{\prime} \mathrm{N}\right.$, $\left.92^{\circ} 57^{\prime} \mathrm{W}\right)$. There was a high intensity of PBLS on Cape Fear trees in this orchard. Terminals with spittle masses containing nymphs were collected from 1 June through 19 August 2004 and on 6 and 20 May and 14 July 2005. Terminals from infected Cape Fear trees were cut, placed in plastic bags, and transported to the Louisiana State University AgCenter Pecan Research-Extension Station in Shreveport, LA. Terminals collected in 2004 were symptomatic. In 2005, collected terminals with nymphs were both symptomatic and asymptomatic (from known infected trees prior to symptom development). Nymphs 
used in transmission tests were transferred directly to test trees by removing them from their spittle masses with a small, softbristled paint brush or by placing the cut terminal with spittle masses onto the test trees. The number of nymphs placed on a tree ranged from 5 to 30 . Nymphs remained on these trees until they died or molted to adults.

Adult pecan spittlebugs were collected by aspirators from terminals. Adults were collected in August and September 2004, from May through September 2005, in May 2006, and in September 2007. Adults collected from symptomatic trees were not given an AAP. Adults collected from asymptomatic tissue were given an AAP before transfer to test trees. AAPs for spittlebug adults were 1 or 2 days. The number of adults on each test tree ranged from 1 to 20. Adults remained on these trees until they died.

One other spittlebug species, the diamond-backed spittlebug, Lepyronia quadrangularis (Say), was also collected and tested for transmission. In September 2005, 10 L. quadrangularis adults were captured in sweep nets from a sorghum plot. These spittlebugs were given 1- or 2day AAPs on detached symptomatic pecan terminals; five specimens were then transferred to each of two test pecan trees for an IAP of 17 to 18 days. After the initial IAP, the six spittlebugs still alive were given another 1-day AAP and a second IAP of 10 days followed by transfer of the four remaining insects to two test trees for 7 days.

Homalodisca insolita transmission tests. From October to early November 2004 , insect sweep nets were used to collect $65 \mathrm{H}$. insolita (Walker), the Johnsongrass sharpshooter, from a sorghum plot at the edge of an orchard at the Pecan Station $\left(32^{\circ} 21.7^{\prime} \mathrm{N}, 93^{\circ} 38.6^{\prime} \mathrm{W}\right)$. The leafhoppers were given 1 - to 3 -day AAPs, and 1 to 10 insects were placed on each of 23 transmission test trees. H. insolita was again collected from a sorghum plot at the Pecan Station from 13 September to 20

Table 1. Summary of transmission of Xylella fastidiosa to pecan by Clastoptera achatina, 2004-2007

\begin{tabular}{lcc}
\hline $\begin{array}{l}\text { Source of } \\
\text { spittlebugs }^{\mathbf{x}}\end{array}$ & $\begin{array}{c}\text { Number of } \\
\text { insects }^{\mathbf{y}}\end{array}$ & $\begin{array}{c}\text { Trees infected/ } \\
\text { trees tested }^{\mathbf{z}}\end{array}$ \\
\hline $\begin{array}{c}\text { Direct orchard } \\
\text { transfer }\end{array}$ & 2,351 nymphs & $0 / 93$ \\
$\begin{array}{c}\text { Direct orchard } \\
\text { transfer }\end{array}$ & 589 adults & $1 / 49$ \\
1-2 day AAP & 283 adults & $4 / 35$ \\
\hline
\end{tabular}

${ }^{\mathrm{x}}$ Spittlebugs were either transferred directly from terminals they were collected on in a pecan orchard or first given an acquisition access period (AAP) on infected pecan tissue.

${ }^{y}$ Total number of insects in a test category.

${ }^{\mathrm{z}}$ Numerator is number of transmission test trees that developed pecan bacterial leaf scorch symptoms and gave a positive serological assay for $X$. fastidiosa. Denominator is total number of trees in the test.
September 2005 (plot destroyed by storm on 24 September). Eighty-nine $H$. insolita were given a 1-day AAP, and 24 of these were given a second 1-day AAP before transfer to fresh test plants. IAPs were 7 to 19 days with 2 to 15 insects on each of 34 trees.

Homalodisca vitripennis transmission tests. In 2005, 41 H. vitripennis (Germar), the glassy-winged sharpshooter (GWSS), were collected from healthy pecan, plumeria, and sorghum and tested for transmission using 16 healthy pecan test trees in the initial exposure following AAPs of 1 to 5 days. In 2006, GWSS were collected from healthy pecan and citrus trees at a pecan orchard $\left(31^{\circ} 3.2^{\prime} \mathrm{N}, 92^{\circ}\right.$ 8.6 $\mathrm{W}$ ) near Hessmer, LA, in June and July. They were given initial AAPs of 1, 2, or 3 days. The IAPs were from 6 to 12 days with 18 test trees used for initial exposure after the AAPs. In May and June 2007, GWSS were collected from the same location and given AAPs on PBLS symptomatic tissue of 1 (76 GWSS), 2 (51 GWSS), or 3 (14 GWSS) days followed by IAPs of generally 7 days. The initial IAPs were comprised of 49 trees with 1 to 5 GWSS on each tree. Following the initial IAPs each year, $H$. vitripennis still living were transferred to additional test trees.

Miscellaneous Cicadellidae transmission tests. Over the course of the study, a few specimens of three other leafhoppers, one Cuerna costalis (Fabricius), three Oncometopia nigricans (Walker), and two Paraulacizes irrorata (Fabricius), were collected from sorghum and pecan and tested for $X$. fastidiosa transmission to pecan. These leafhoppers were given AAPs of 1 to 2 days, then transferred to test trees as described in general transmission test procedures.

Data analyses. Percent transmission by insect species was compared using the least significant difference (LSD, $\alpha=0.05$ ) test. Likewise, comparison of percent transmission between insects given a 1-day or more than 1-day AAP was made with the LSD test.

Serological assay of test trees and insects. In addition to visual determination of PBLS symptoms, all test trees were screened for infection by enzyme-linked immunosorbent assay (ELISA; doubleantibody sandwich [DAS]-ELISA for $X$. fastidiosa, Agdia Inc., Elkhart, IN). Generally, assays included sections of three rachises of each tree, with rachises from symptomatic leaves, if present. Tissue sections were placed in sample bags (Agdia) and pulverized in 4 to $5 \mathrm{ml}$ of cold extraction buffer with a pestle. Positive reactions were recorded for trees with an absorbance $(640 \mathrm{~nm})$ at least three times greater than tissue from noninfected trees in the greenhouse.

Test trees that developed symptoms during the same year that they were exposed to insects were assayed for infection upon symptom development. All test trees were assayed in July or August of the year following insect exposure. All test trees from 2004 and 2005 were monitored for symptoms and assayed again 2 years following vector exposure. Because no additional infections were found during the second year after IAP for the 2004 and 2005 trees, the second-year assay was discontinued for the 2006 and 2007 trees. Trees that did not exhibit PBLS symptoms were assayed by combining tissue from three trees that were exposed to the same insect species to make a single ELISA sample. A negative reaction indicated that none of the trees in the sample were infected.

Samples of pecan spittlebug nymphs and adults and adult leafhoppers were also tested for the presence of $X$. fastidiosa by ELISA. Whole spittlebugs or heads of leafhoppers were homogenized in $1 \mathrm{ml}$ of cold extraction buffer with a mortar and pestle. Spittlebug nymphs were assayed on the same day they were collected from infected trees or within $24 \mathrm{~h}$ of collection. Assay samples consisted of 10, 20, or 40 nymphs, and one sample of 125 . Assay samples of spittlebug adults had 6, 10, or 20 spittlebugs collected primarily from the nuts of asymptomatic terminals of infected trees. H. insolita ELISA samples were from the specimens used in transmission tests and then stored at $4{ }^{\circ} \mathrm{C}$. Two samples were assayed for X. fastidiosa, one with 12 and the other with 24 insect heads. $H$. vitripennis ELISA samples were collected from transmission test trees and from AAP sources and then stored at $4^{\circ} \mathrm{C}$. GWSS samples had 1 to 16 insect heads.

Insect identification. Samples of insects used in transmission tests were sent to the Louisiana State University AgCenter Department of Entomology for identification.

\section{RESULTS}

Spittlebug transmission tests. Pecan spittlebug nymphs did not transmit $X$. fastidiosa in the tests reported here (Table 1). Adult pecan spittlebugs transferred directly from symptomatic tissue to test pecan trees transmitted $X$. fastidiosa to $2 \%$ of the trees. Adult pecan spittlebugs given an AAP on infected pecan tissue transmitted the pathogen to $11.4 \%$ of the test trees (Table $1)$. The five test trees that were infected were exposed to 7 to 20 spittlebugs.

One of six IAP trees tested with two specimens of $L$. quadrangularis became infected, indicating pathogen transmission to pecan by this spittlebug. This is apparently the first report of this spittlebug as a vector of $X$. fastidiosa.

$H$. insolita transmission tests. Nearly $16 \%$ of the first pecan trees exposed to $H$. insolita following AAPs were infected (Table 2). Fourteen percent of the trees exposed to $H$. insolita following transfer from the first group of test trees were infected (Table 2). H. insolita given a second 
AAP following the initial IAP transmitted to $60 \%$ of the next test trees (Table 2). Transmission by $H$. insolita during the 2year test period was with four to eight insects on a tree.

$H$. vitripennis transmission tests. Of the first group of test trees exposed to $H$. vitripennis following AAPs, 9.6\% were infected (Table 3). Successive transfers to additional test trees without another AAP resulted in transmission to $1.9 \%$ of the trees. No transmission was recorded for the eight $H$. vitripennis given a second AAP (Table 3). Transmission by $H$. vitripennis during the 3-year test period was with one to five insects on a tree.

Miscellaneous Cicadellidae transmission tests. Of the three leafhopper species for which only a few specimens were collected and tested for transmission of the pathogen to pecan, the single specimen of Cuerna costalis, the lateral-lined sharpshooter, transmitted $X$. fastidiosa to two pecan trees; whereas the three Oncometopia nigricans and the two Paraulacizes irrorata did not transmit.

Data analyses. Because few positive transmission events by $H$. vitripennis occurred with less than four insects on a tree and few trees had less than four pecan spittlebugs or $H$. insolita, comparisons across insects were made using only trees with four or more insects. Results from all years were combined for the analysis. There were no significant differences in the percent transmission between $C$. achatina adults, $H$. insolita, and $H$. vitripennis when each tree was exposed to four or more insects following an AAP (Table 4).

No significant differences were detected in percent transmission for GWSS with a 1-day AAP or AAPs of 2 days or more (Table 5). All IAP trees with the first exposure to GWSS following an AAP from 2005 through 2007 were used in this analysis. The analysis for the effect of length of AAP on transmission efficiency was done only with the GWSS because few insects of the other species had AAPs longer than 1 day.

Serological assay of insects for $X$. fastidiosa. X. fastidiosa was not detected by serological assay in $C$. achatina nymphs or adults when collected from symptomatic or asymptomatic terminals of infected trees (Table 6). One of two groups of $H$. insolita used in ELISA was positive for the bacterium (Table 6); however, these groups had not been sorted by the test trees they were on.

$X$. fastidiosa was detected by ELISA in 2 of 6 groups of $H$. vitripennis that had transmitted to test trees (Table 6). Conversely, the bacterium was detected in 5 of the 41 GWSS groups that did not transmit to any of their test trees (Table 6). GWSS in these five groups had been exposed to a total of 39 test trees with 7-day IAPs. None of the 39 test trees that had been exposed to at least one infectious insect were infected. $X$. fastidiosa was also detected in $38 \%$ of the GWSS that were given an AAP but died before the IAPs.

Greenhouse controls. Throughout the pathogen transmission tests, none of the extra trees not exposed to insects developed PBLS symptoms. Serological assays of 10 or more of these trees each year were negative. Only trees that had been intentionally exposed to insects and that developed symptoms of the disease tested positive for the bacterium by ELISA.

\section{DISCUSSION}

During pecan spittlebug collection, we observed that adults tended to be more prevalent on asymptomatic terminals of infected trees than on terminals with visible PBLS. Similar host selectivity by other $X$. fastidiosa vectors was reported with citrus (24). This suggests that spittlebug feeding preference is for tissue without restricted xylem flow. This habit may affect transmission rates in nature. Even a low transmission rate, as recorded in this study, could result in significant disease increase when hundreds of spittlebugs feed on trees during high population cycles. In California, a vineyard area with vector populations of low transmission efficiency and low vector numbers resulted in a rate of Pierce's disease spread comparable to that of a vineyard area with vector species of higher transmission efficiency (31). Results of a meta-analysis of transmission experiments indicated that transmission was positively correlated with the number of $H$. vitripennis but not with length of acquisition periods for the bacterium or length of inoculation access periods (13).

Because the number of pecan spittlebugs on pecan trees could easily be in the hundreds (43), our data suggest that this insect could be a significant vector of $X$. fastidiosa in pecan orchards. Although there has been uncertainty about the importance of pecan spittlebugs as an economic pest in commercial orchards $(47,48)$, their identification as a vector of $X$. fastidiosa in pecan increases their significance in commercial pecan culture. Because spittle masses are easily seen prior to adult emergence, it should be possible to greatly reduce the transmission

Table 2. Summary of Xylella fastidiosa transmission by Homalodisca insolita to pecan, 2004-2005

\begin{tabular}{lcccc}
\hline Collection source & AAP $^{\mathbf{w}}$ & IAP $^{\mathbf{x}}$ & $\begin{array}{c}\text { No. of insects } \\
\text { tested }\end{array}$ & $\begin{array}{c}\text { Infected trees/ } \\
\text { trees tested }^{\mathbf{y}}\end{array}$ \\
\hline Sorghum & $1-3$ & $1-20$ & 154 & $6 / 38$ \\
Test tree & 1 & $10-12$ & 24 & $3 / 5$ \\
Test tree & 0 & $7-11$ & 35 & $2 / 14$ \\
\hline
\end{tabular}

${ }^{\mathrm{w}} \mathrm{AAP}=$ acquisition access period, number of days insects were caged on $X$. fastidiosa-infected source. All source tissue was infected symptomatic pecan terminals.

${ }^{\mathrm{x}} \mathrm{IAP}=$ inoculation access period, the number of days insects were caged on a transmission test tree.

${ }^{y}$ Numerator is number of transmission test trees that developed pecan bacterial leaf scorch symptoms and gave a positive serological assay for $X$. fastidiosa. Denominator is total number of trees in the test.

${ }^{\mathrm{z}}$ Collected from test trees and transferred to additional test trees successively. Sometimes an additional AAP was given between IAPs.

Table 3. Summary of Xylella fastidiosa transmission by Homalodisca vitripennis to pecan, 2005-2007

\begin{tabular}{lcccc}
\hline Collection source & AAP & IAP & $\begin{array}{c}\text { Number of } \\
\text { insects tested }\end{array}$ & $\begin{array}{c}\text { Infected trees/ } \\
\text { trees tested }^{\mathbf{x}}\end{array}$ \\
\hline Host $^{\mathrm{y}}$ & $1-5$ & $4-60$ & 267 & $8 / 83$ \\
Test tree & $\mathrm{z}$ & $4-12$ & 204 & $4 / 216$ \\
Test tree & $1-2$ & $7-10$ & 8 & $0 / 5$ \\
\hline
\end{tabular}

${ }^{\mathrm{v}} \mathrm{AAP}=$ acquisition access period, number of days insects were caged on $X$. fastidios $a$-infected pecan tissue.

${ }^{\mathrm{w}} \mathrm{IAP}=$ inoculation access period, number of days insects were caged on noninfected pecan trees following the AAP.

${ }^{\mathrm{x}}$ Numerator is number of transmission test trees that developed pecan bacterial leaf scorch symptoms and gave a positive serological assay for $X$. fastidiosa. Denominator is total number of trees in the test.

${ }^{\mathrm{y}} H$. vitripennis was collected from several host species including pecan, peach, citrus, sorghum, and plumeria.

${ }^{\mathrm{z}}$ Collected from test trees and transferred to additional test trees successively. Sometimes an additional AAP was given between IAPs.

Table 4. Infection data for IAPy trees with four or more insects each, 2004-2007

\begin{tabular}{|c|c|c|c|}
\hline IAP trees & $\begin{array}{l}\text { Clastoptera } \\
\text { achatina }\end{array}$ & $\begin{array}{c}\text { Homalodisca } \\
\text { insolita }\end{array}$ & $\begin{array}{c}\text { Homalodisca } \\
\text { vitripennis }\end{array}$ \\
\hline Number of IAP trees & 35 & 49 & 91 \\
\hline Number of trees infected & 4 & 11 & 8 \\
\hline Percent IAP trees infected ${ }^{z}$ & $11.4 \mathrm{a}$ & $22.4 \mathrm{a}$ & $13.2 \mathrm{a}$ \\
\hline
\end{tabular}

${ }^{\mathrm{y}} \mathrm{IAP}=$ inoculation access period, following the Xylella fastidiosa acquisition access period.

${ }^{\mathrm{z}}$ Values in a row followed by the same letter are not significantly different by $\operatorname{LSD}(\alpha=0.05)$. 
potential of this vector with insecticide applications.

In contrast to the adult pecan spittlebug, we did not detect any transmission of $X$. fastidiosa by the nymphs, which were transferred directly from infected trees to test trees, where they quickly formed new spittle masses and continued development into adults. Due to the large number of nymphs tested, even though they were not given AAPs, it was surprising that no transmission occurred, as nymphs of other vector species acquire and transmit $X$. fastidiosa $(32,41)$. The pecan spittlebug overwinters as eggs beneath bark (43); thus, the nymphs would have to acquire the bacterium by feeding on infected pecan tissue where they hatch. When the nymphs develop in the spring, the populations of $X$. fastidiosa may be too low in the new terminal growth for efficient acquisition (17). Nonetheless, the ability of spittlebug nymphs to transmit the bacterium in nature would likely be epidemiologically irrelevant because nymphs develop within spittle masses on their pecan host and do not move to other trees until molting to adults, at which time they would lose the bacterium (32).

$X$. fastidiosa was not detected in pecan spittlebug nymphs or adults by ELISA, suggesting that it either was not acquired, or was below the population density necessary for detection by the ELISA test $(27,33)$. Low bacterial numbers in the spittlebugs may be the reason for lack of detection since transmission by adults did occur.

In addition to the pecan spittlebug, which lives entirely on Carya species, the spittlebug Lepyronia quadrangularis transmitted $X$. fastidiosa when caged on pecan. This spittlebug is common throughout the eastern United States and feeds primarily on weedy hosts (14). While it is not known if this insect feeds on pecan in nature, it emphasizes the likelihood of a large number of potential vectors that may occasionally transmit the pathogen to pecan.

There are no reports of leafhopper species that typically occur in pecan orchards. However, because leafhoppers are considered to be the primary vectors of $X$. fas-

Table 5. Homalodisca vitripennis transmission data for the initial IAPx tree, 2005-2007

\begin{tabular}{lcc}
\hline IAP trees & $\begin{array}{c}\text { AAPy } \\
=\mathbf{1} \text { day }\end{array}$ & $\begin{array}{c}\text { AAP } \\
\mathbf{2 2} \text { days }\end{array}$ \\
\hline Noninfected trees & 56 & 49 \\
Infected trees & 9 & 7 \\
Percent infected & $13.8 \mathrm{a}$ & $12.5 \mathrm{a}$ \\
\hline${ }^{\mathrm{x}}$ IAP $=$ inoculation & access period, following \\
Xylella fastidiosa acquisition access period. \\
y AAP = acquisition access period, number of \\
days that insects were caged on $X$. fastidiosa- \\
infected pecan tissue. \\
z Values in a row followed by the same letter are \\
not significantly different by LSD $(\alpha=0.05)$.
\end{tabular}

tidiosa, an attempt was made to test leafhopper species collected in and near pecan orchards for their ability to transmit the pathogen to pecan. Sorghum is sometimes recommended as a trap crop for stinkbug pests in pecan orchards (25). A sorghum plot planted for this purpose was a source of several known leafhopper vectors of $X$. fastidiosa. $H$. insolita, a vector of $X$. fastidiosa to peach in the southeastern United States $(28,44)$, was collected from sorghum. Although it was not collected from pecan in this study, it transmitted to pecan in our tests, and has since been trapped in pecan orchards (R. Sanderlin, unpublished).

The GWSS is native to the southeastern United States and is an important vector of $X$. fastidiosa to several plant species $(4,5,11,12,21,32,34)$. It is a major threat in the spread of the pathogen because it is a polyphagous voracious feeder $(7,45)$. The GWSS in our study was initially captured from sorghum, and subsequently observed to be a common feeder on succulent pecan shoot growth in several orchards in Louisiana. GWSS tended to feed in groups on young vigorous pecan shoots, often lining up in rows on these shoots. The GWSS were not easily driven from pecan when disturbed, usually returning immediately to the same tree. They were present in the highest numbers on pecan from about 11 A.M. to 1 P.M., preferring terminals in sunlight over shade, and were difficult to find on pecan from dawn to midmorning in the summer months. GWSS activity on Prunus has been reported to be higher at night than during daylight; nighttime activity was not monitored on pecan (7).

In light of the preference for young vigorous pecan growth in GWSS, and perhaps in other vectors, it is interesting to note that PBLS is often first observed developing on current year's growth in the tops of trees where sunlight is most prevalent. Although not as efficient a vector as $H$.

Table 6. Serological assay of insects for Xylella fastidiosat

\begin{tabular}{llcc}
\hline Species & \multicolumn{1}{c}{ Source } & $\begin{array}{c}\text { No. of insects } \\
\text { assayed }^{\mathbf{u}}\end{array}$ & $\begin{array}{c}\text { No. of positive assays/ } \\
\text { No. of assays }^{\mathbf{w}}\end{array}$ \\
\hline Clastoptera achatina & Terminals with PBLS & 2,035 nymphs & $0 / 205$ \\
C. achatina & Asymptomatic terminals & 270 nymphs & $0 / 12$ \\
& from infected trees & 132 adults & $0 / 10$ \\
Homalodisca insolita & IAP trees & $36^{\mathrm{x}}$ & $1 / 2$ \\
Homalodisca vitripennis & AAP source & 66 & $6 / 16$ \\
H. vitripennis & IAP trees (infected) & 24 & $2 / 6^{\mathrm{y}}$ \\
H. vitripennis & IAP trees (noninfected) & 119 & $5 / 41^{\mathrm{z}}$ \\
\hline
\end{tabular}

${ }^{\mathrm{t}}$ ELISA kit (Agdia) for $X$. fastidiosa used for serology. Unless noted, all insects assayed were adults.

u Asymptomatic terminals had lost most of their original foliage from pecan bacterial leaf scorch (PBLS) and produced a second flush of foliage that was not yet symptomatic. IAP (inoculation access period) trees were used in transmission tests and the insects on them collected for assay after they died. Insects on AAP (acquisition access period) source were dead when retrieved and were not exposed to IAP trees; they were stored at $4^{\circ} \mathrm{C}$ until enzyme-linked immunosorbent assay (ELISA).

$\checkmark$ Total number of insects used in a group of assays.

${ }^{w}$ Numerator is number of assays positive for $X$. fastidiosa. Denominator is total number of ELISAs for a group.

${ }^{x}$ Not known if any of these insects transmitted during IAPs.

y Each of the six groups in these assays transmitted X. fastidiosa.

${ }^{\mathrm{z}}$ None of the insects in these assays transmitted X. fastidiosa to any of their 39 IAP trees. 
studies have shown that GWSS feed on secondary stem tissue and can transmit $X$. fastidiosa to 2-year-old stems $(5,44)$. GWSS can also acquire and transmit the bacterium when feeding on dormant tissues $(4,6)$. As reported for grapevine $(5,32)$, a 1-day AAP was as efficient as longer AAPs for acquisition and transmission of $X$. fastidiosa to pecan. The observation of a lack of increase in the numbers of a vector that transmit the pathogen when given longer exposure periods to infected tissue is an important area that needs more investigation.

Similar to phony peach disease, clear differences in the ability of three species of vectors to transmit the pathogen to pecan were not observed (46). Other studies have reported both significant and not significant differences in species transmission efficiencies with both single insects and groups of insects $(23,30,34)$. The overall transmission rate by vectors to pecan suggests that either pecan is difficult to infect, the acquisition from pecan tissue is lower than from other hosts that have been studied, or there is a lack of feeding on PBLS symptomatic tissue during AAP $(3,17,24)$.

Detection of $X$. fastidiosa in $H$. insolita and $H$. vitripennis by ELISA was erratic. The bacterium was not detected in all groups that transmitted and was sometimes detected in groups that did not transmit. Failure of some insects to transmit the bacterium even though they were carriers based on ELISA results, and the low successive transmission rates in the tests, imply that exposure of pecan trees to infectious vectors does not always result in infection of the trees.

Only one specimen of Cuerna costalis was tested on pecan, but its transmission to two trees suggests that, as with peach, even though this species is primarily a grass feeder, it has the potential to be a vector on pecan $(45,46)$. Even though Oncometopia nigricans, a vector on peach, grape, and citrus $(1,9,46)$, did not transmit to pecan in our very limited testing, the fact that it was collected from pecan and survived for nearly 100 days on pecan test trees indicates that further testing of this leafhopper as a $X$. fastidiosa vector on pecan is warranted.

Several insecticides have been reported to quickly kill leafhoppers and reduce transmission of $X$. fastidiosa in experimental tests on other crops $(8,10,15,18,29)$. Some of these insecticides are registered for use on pecan (22). Studies are needed to determine the vector species that occur regularly in pecan orchards and their population dynamics to establish if insecticides would be useful for reducing PBLS spread (2). Management of vectors in pecan orchards along with control of pathogen introduction into orchards through hotwater treatment of scions (37) may afford methods to significantly lessen the spread of PBLS in commercial orchards.

\section{ACKNOWLEDGMENTS}

We thank Christopher Carlton, Professor, and Stephanie Gil, Louisiana State Arthropod Museum, Department of Entomology, Louisiana State University Agricultural Center, for identification of leafhopper species used in this study.

\section{LITERATURE CITED}

1. Adlerz, W. C., and Hopkins, D. L. 1979. Natural infectivity of two sharpshooters, Oncometopia nigricans, Homalodisca coagulate, vectors of Pierces disease of grape, Vitis vinifera cultivar Carignane in Florida. J. Econ. Entomol. 72:916-919.

2. Almeida, R. P., Blua, M. J., Lopes, J. R. S., and Purcell, A. H. 2005. Vector transmission of Xylella fastidiosa: Applying fundamental knowledge to generate disease management strategies. Ann. Entomol. Soc. Am. 98:775786.

3. Almeida, R. P. P., Pereira, E. F., Purcell, A. H., and Lopes, J. R. S. 2001. Multiplication and movement of a citrus strain of Xylella fastidiosa within sweet orange. Plant Dis. 85:382386.

4. Almeida, R. P. P., and Purcell, A. H. 2003. Homalodisca coagulata (Hemiptera, Cicadellidae) transmission of Xylella fastidiosa to almond. Plant Dis. 87:1255-1259.

5. Almeida, R. P., and Purcell, A. H. 2003. Transmission of Xylella fastidiosa to grapevines by Homalodisca coagulata (Hemiptera: Cicadellidae). J. Econ. Entomol. 96:264-271.

6. Almeida, R. P. P., Wistrom, C., Hill, B. L., and Purcell, A. H. 2005. Vector transmission of Xylella fastidiosa to dormant grape. Plant Dis. 89:419-424.

7. Andersen, P. C., Mizell, R. F., Brodbeck, B. V., Beckman, T. G., and Krewer, G. 2008. Abundance and consumption rate of Glassy-Winged Sharpshooter (Hemiptera: Cicadellidae) on peaches and plums. J. Entomol. Sci. 43:394407.

8. Bethke, J. A., Blua, M. J., and Redak, R. A. 2001. Effect of selected insecticides on Homalodisca coagulata (Homoptera: Cicadellidae) and transmission of oleander leaf scorch in a greenhouse study. J. Econ. Entomol. 94:1031-1036

9. Brlansky, R. H., Damsteegt, V. D., and Hartung, J. S. 2002. Transmission of the citrus variegated chlorosis bacterium Xylella fastidiosa with the sharpshooter Oncometopia nigricans. Plant Dis. 86:1237-1239.

10. Byrne, F. J., and Toscano, N. C. 2008. Understanding the dynamics of neonicotinoid insecticidal activity against the glassy-winged sharpshooter: Development of target thresholds in grapevines. Pages 55-56 in: Proc. 2008 Pierce's Dis. Res. Sympos. CDFA. T. Esser, P. Blincoe, D. West, S. Veling, R. Randhawa, and J. LeMasters, ed. Copeland Printing, Sacramento, CA

11. Costa, H. S., Blua, M. S., Bethke, J. A., and Redak, R. A. 2000. Transmission of Xylella fastidiosa to oleander by the glassywinged sharpshooter, Homadodisca coagulata. HortScience 35:1265-1267.

12. Damsteegt, V. D., Brlansky, R. H., Phillips, P. A., and Roy, A. 2006. Transmission of Xylella fastidiosa, causal agent of citrus variegated chlorosis, by the glassy-winged sharpshooter, Homalodisca coagulata. Plant Dis. 90:567570.

13. Daugherty, M. P., and Almeida, R. P. 2009. Estimating Xylella fastidiosa transmission parameters: Decoupling sharpshooter number and feeding period. Entomol. Exp. Applic. 132:84-92.

14. Doering, K. C. 1922. Biology and morphology of Lepyronia quadrangularis (Say) - Homoptera, Cercopidae. Kansas University Science Bull. 14:515-587

15. Dutcher, J. D., Krewer, G. W., and Mullinix, B.
G. 2005. Imidacloprid insecticide slows development of phony peach and plum leaf scald. HortTechnology 15:642-645.

16. Gould, A. B., and Lashomb, J. H. 2005. Bacterial leaf scorch of shade trees. American Phytopathological Society, St. Paul, MN. Online. http://www.apsnet.org/online/feature/bls.

17. Hill, B. L., and Purcell, A. H. 1997. Populations of Xylella fastidiosa in plants required for transmission by an efficient vector. Phytopathology 87:1197-1201.

18. Hix, R. L., Toscano, N. C., and Gispert, C. 2003. Area-wide management of the glassywinged sharpshooter in the Temecula and Coachella valleys. Pages 292-294 in: Proc. 2003 Pierce's Dis. Res. Sympos. CDFA. M. A. Tariq, S. Oswalt, P. Blincoe, R. Spencer, L. Houser, A. Ba, and T. Esser, ed. Copeland Printing, Sacramento, CA

19. Hopkins, D. L., and Purcell, A. H. 2002. Xy lella fastidiosa: Cause of Pierce's disease of grapevine and other emergent diseases. Plant Dis. 86:1056-1066.

20. Lashomb, J., Gould, A. B., Iskra, A., and Hamilton, G. 2002. Bacterial leaf scorch of amenity trees: A wide-spread problem of economic significance to the urban forest. U.S Dep. Agric. For. Serv. NA-TP-01-01.

21. Leininger, T. D., Schiff, N. M., and Corbin, K C. 2004. The glassy-winged sharpshooter transmits Xylella fastidiosa between sycamore trees. (Abstr.) Phytopathology 94:S59.

22. Louisiana Insect Pest Management Guide. 2008. Louisiana State University Agricultural Center Publ. 1838. pp. 138-139.

23. Marucci, R. C., Lopes, J. S., and Cavichioli, R. R. 2008. Transmission efficiency of Xylella fastidiosa by sharpshooters (Hemiptera: Cicadellidae) in coffee and citrus. J. Econ. Entomol. 101:1114-1121.

24. Marucci, R. C., Lopes, J. S., Vendramim, J. D., and Corrente, J. E. 2005. Influence of Xylella fastidiosa infection of citrus on host selection by leafhopper vectors. Entomol. Exp. Applic. 117:95-103

25. Mizell, R. F., Riddle, T. C., and Blount, A. S. 2008. Trap cropping for management of stink and leaffooted bugs. Proc. Fla. St. Hortic. Soc. 121:377-382.

26. Myers, A. L., Sutton, T. B., Abad, J. A., and Kennedy, G. G. 2007. Pierce's disease of grapevine: Identification of the primary vectors in North Carolina. Phytopathology 97:14401450

27. Nomé, S. F., Raju, B. C., Goheen, A. C. Nyland, G., and Docampo, D. 1980. Enzymelinked immunosorbent assay for Pierce's disease bacteria in plant tissue. Phytopathology 70:746-749.

28. Pollard, H. N., Turner, W. F., and Kaloostian, G. H. 1959. Invasion of the southeast by a western leafhopper, Homalodisca insolita. J. Econ. Entomol. 52:359-360.

29. Purcell, A. H. 1979. Control of the blue-green sharpshooter and effects on the spread of Pierce's disease of grapevine. J. Econ. Entomol. 72:887-892

30. Purcell, A. H. 1980. Almond leaf scorch: Leafhopper and spittlebug vectors. J. Econ Entomol. 73:834-838

31. Purcell, A. H. 1981. Vector preference and inoculation efficiency as components of resistance to Pierce's disease in European grape cultivars. Phytopathology 71:429-435.

32. Purcell, A. H., and Finlay, A. H. 1979. Evidence for noncirculative transmission of Pierce's disease bacterium by sharpshooter leafhoppers. Phytopathology 69:393-395.

33. Raju, B. C., Goheen, A. C., and Frazier, N. W. 1983. Occurrence of Pierce's disease bacteria in plants and vectors in California. Phytopathology 73:1309-1313.

34. Redak, R. A., Purcell, A. H., Lopes, J. R., Blua, M. J., Mizell, R. F., and Anderson, P. C. 
2004. The biology of xylem fluid-feeding insect vectors of Xylella fastidiosa and their relation to disease epidemiology. Annu. Rev. Entomol. 49:243-270.

35. Sanderlin, R. S., and Heyderich-Alger, K. I. 2000. Evidence that Xylella fastidiosa can cause leaf scorch disease of pecan. Plant Dis. 84:1282-1286

36. Sanderlin, R. S., and Heyderich-Alger, K. I. 2003. Effects of pecan bacterial leaf scorch on growth and yield components of cultivar Cape Fear. Plant Dis. 87:259-262.

37. Sanderlin, R. S., and Melanson, R. A. 2008. Reduction of Xylella fastidiosa transmission through pecan scion wood by hot-water treatment. Plant Dis. 92:1124-1126.

38. Schaad, N. W., Postnikova, E., Lacy, G., Fatmi, M., and Chang, C. J. 2004. Xylella fastidiosa subspecies: $X$. fastidiosa subsp. piercei subsp. nov., $X$. fastidiosa subsp. multiplex subsp. nov., and $X$. fastidiosa subsp. pauca subsp. nov.
Syst. Appl. Microbiol. 27:290-300.

39. Schaad, N. W., Postnikova, E., Lacy, G., Fatmi, M., and Chang, C. J. 2004. Erratum. Xylella fastidiosa subspecies: $X$. fastidiosa subsp. [correction] fastidiosa [correction], subsp. nov., $X$. fastidiosa subsp. multiplex subsp. nov., and $X$. fastidiosa subsp. pauca subsp. nov. Syst. Appl. Microbiol. 27:763.

40. Schuenzel, E. L., Scally, M., Stouthamer, R., and Nunney, L. 2005. A multigene phylogenetic study of clonal diversity and divergence in North American strains of the plant pathogen Xylella fastidiosa. Appl. Environ. Microbiol. 71:3832-3839.

41. Severin, H. H. P. 1949. Transmission of the virus of Pierce's disease of grapevines by leafhoppers. Hilgardia 19:190-206.

42. Sparks, D. 2002. Pecan Diseases. Pages 51-52 in: Compendium of Nut Crop Diseases in Temperate Zones. B. L. Teviodale, T. J. Michailides, and J. W. Pscheidt, ed. American
Phytopathological Society, St. Paul, MN

43. Tedders, W. L. 1995. Identity of spittlebug on pecan and life history of Clastophera achatina (Homoptera: Cercopidae). J. Econ. Entomol. 88:1641-1649.

44. Turner, W. F., and Pollard, H. N. 1955. Additional leafhopper vectors of phony peach. J. Econ. Entomol. 48:771-772.

45. Turner, W. F., and Pollard, H. N. 1959. Life histories and behavior of five insect vectors of phony peach disease. U.S. Dep. Agric. Tech. Bull. 1188:1-28.

46. Turner, W. F., and Pollard, H. N. 1959. Insect transmission of phony peach disease. U.S Dep. Agric. Tech. Bull. 1193:1-27.

47. Wells, L., ed. 2007. Spittlebugs. Page 148 in: Southeastern Pecan Growers Handb. Pub. Univ. Georgia Coop. Ext. Serv. Bull. 1327.

48. Worley, R. E. 2002. Spittlebugs. Page 315 in: Compendium of Pecan Production and Research. Edwards Brothers, Ann Arbor, MI. 